\title{
Public-Private Partnership Model Used in the Taipei Central Station Project Research
}

\author{
Mou-Chung Tseng, Chien-Wen Peng \\ National Taipei University, Taiwan, R.O.C.
}

\begin{abstract}
In view of the lack of financial aid and the migration of industries, the role of local governments shifted from social reproduction to development and production, which made the development of the local economy their main responsibility. The local governments hence have to face challenges in their management in regards to the arising changes and needs. This Taipei Central Bus Station Build Operate Transfer (BOT) project of urban formation and development is not only a trend in countries around the globe; it is also an area the Taiwanese governments are actively involved in. With the impact of urbanization, the size of highly functional cities has surpassed core city administrative regions; therefore, this has generated various planning, administrative and policy issues. This study examines the public-private partnership (PPP) views on urban development; the research methodology will be designed to focus on qualitative research, the following conclusions were made: (1) The basic goal of global city competitiveness of Taipei was promoted by implementing "qlubarnization", a spatial development strategy dependent on intercalary abilities. (2) Taipei is located in the hub of Asia, linking mainland China and Taiwan, facing the world, peaceful and stable, rich and diverse in culture, such that adopting the "hybrid or mixed-use development model" will allow "the national gate of the country program - Central Station, Central Park" to become an international city brand. (3) Taking the "Taipei Main Station PPPs model development of the Taipei Central Bus Station BOT project of nine precincts specific land development projects" as a key success indicator, the government took privatization or PPP into consideration, loosened the monopoly on urban infrastructure, created infrastructure services and a maintenance market, positioned the city as a "supranational" entity in terms of capital flow, and sought a coherent land policy.
\end{abstract}

Keywords: public-private partnership, urban development, globalization, sustainable development

\section{Introduction}

Considerable changes have already occurred in international relations and the definition of roles among national and sub-national governments. Sustainable development is a diverse concept aiming at urban development and city governance and involving three aspects, namely, ecology, livelihood, and production. It is implemented at the city governance level. The three core requirements derived from these four factors include environmental requirements (such as long-term protection of the global environment), social requirements (such as impartiality and improved social harmony between races, countries, genders, and social

Mou-Chung Tseng, Doctoral Candidate, Department of Real Estate and Built Environment, National Taipei University, Taiwan, R.O.C.

Chien-Wen Peng, Professor, Department of Real Estate and Built Environment, National Taipei University, Taiwan, R.O.C. 
groups), and system requirements (such as ensuring participation in political decisions and making participation a prerequisite for the peaceful resolution of conflicts) (Lee, 2007).

\section{Background of the Study}

The motivation for this study was the differing definitions of globalization. Based on different theoretical schools, the following four views can be distinguished: (1) According to neo-Marxists, globalization consists of the restoration of capitalism and imperialism. (2) According to the followers of neoliberalism, globalization consists of the global integration of economies and markets, which contributes to the optimization of world resources. (3) Transformation lists represented by Giddens suggest that globalization is the main force driving social, political, and economic transformation, as well as the restructuring of the modern social and global order. (4) According to hyper globalists, globalization is a myth that refers only to the internationalization of the economies of developed countries (Jan, 2001). The neoliberal view of urban development under globalization was a product of the economic restructuring process in the late 1970s and early 1980s, during which the role of city governments changed substantially.

Local effects of the central government's liberalization measures

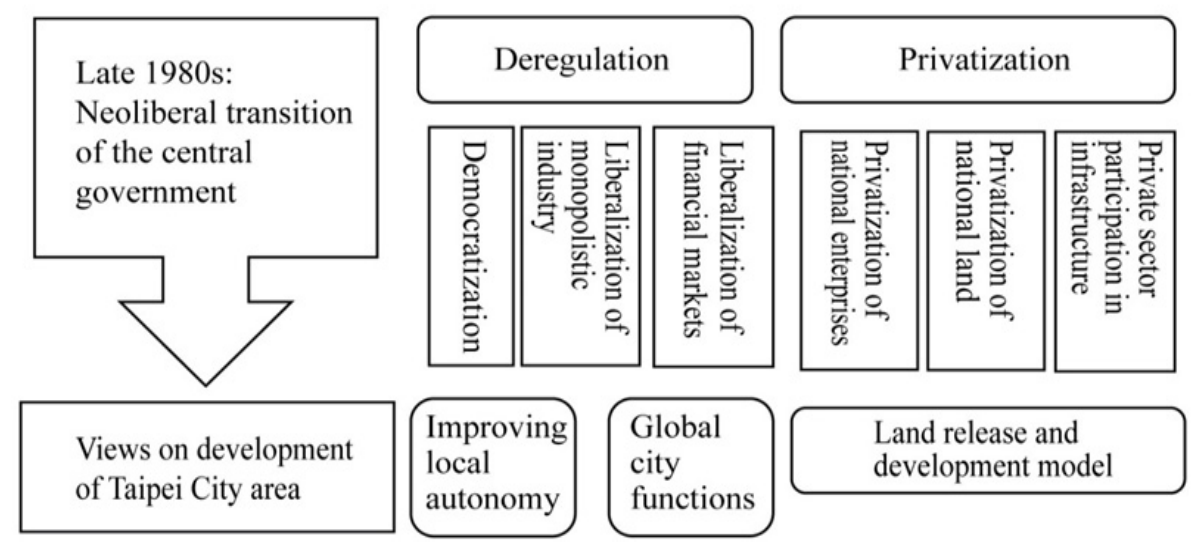

Figure 1. Local effects of neoliberalism. Data source: Compiled by this study.

\section{Motivation of the Study}

The Taipei metropolitan area has the characteristics of a developmental state. Its functions and roles are fixed and closely linked with the overall economic development of Taiwan. Under the pressure of global economic restructuring in the mid-1980s, development shifted toward the neoliberal model and key democratization steps were undertaken at the political level. This study aimed to explore the characteristics of city administration transformation and the implications of neoliberal practice in Taipei's transition into a neoliberal city within a large-scale urban development project involving the economic and spatial transformation of Taipei. In view of the competition for capital among global cities, urban public institutions and infrastructures are moving toward privatization, which has loosened the grip of monopolies that were present in the urban infrastructure sector, created markets for infrastructure services and maintenance, and can be seen as an attempt by cities to position themselves as "supranational" entities with respect to capital flow. Thus, the importance of using the public-private partnership (PPP) model to examine city governance in sustainable urban development is self-evident. 
This study aimed to analyze the fulfilment of economic demands for economic development, urban space transformation, and sustainable urban development through the neoliberal urban development and city governance of Taipei. The objectives of this study were as follows: (1) To promote the primary goal of helping Taipei to achieve global city competitiveness by implementing "qlubarnization", a spatial development strategy dependent on intercalary capabilities. (2) Taipei is located in the hub of Asia, linking mainland China and Taiwan, facing the world, peaceful and stable, rich and diverse in culture, such that adopting the "hybrid or mixed-use development model" will allow "The national gate program-Central Station, Central Park" to become an international city brand. Taking the "Taipei Main Station Turn of nine precincts specific land development projects" as a key success indicator, the government took the PPP model into consideration, loosened the monopoly on urban infrastructure, created infrastructure services and a maintenance market, positioned the city as a "supranational" entity with respect to capital flow, and sought a coherent land policy.

This study examined neoliberal urban development and city governance issues. With regard to research methods, this study performed a literature analysis by reviewing studies and theories regarding the effects of sustainable development, sustainable urban development, and major development projects on urban and rural development and regional equilibrium in order to analyze the individual and overall development issues encountered in governing Taipei. In addition, a case study was conducted in order to explore city governance research status, as well as the characteristics and issues of city governance development in Taiwan.

\section{Literature Review}

In the 1950-60s, due to a heavy fiscal burden and insufficient public executive effectiveness during public construction and administration in Europe and America, the financial resources and capabilities of the private sector were used to support the public sector. However, the "privatization" method touched upon the issues of regulatory compliance and government supervision. The developed functional type of privatization, the PPPs model, offered a compromise as it met the know-how requirement of private industry and provided lean administration, while avoiding the false label of "privatization". The previous "Verwaltungsmonopole" was transformed into "Privatmonopole", giving rise to the PPPs model that has become an unstoppable ideological trend. The followings are important issues in both urban construction and public policy. In the welfare state era, central governments in most European countries strongly protected the national economic system and constructed public facilities in urban areas to provide living space for residents. However, in the 1980s, two external environmental factors affecting urban development emerged, causing drastic changes in central government systems. The first factor was the new orientation toward economic globalization and market liberalization. The second factor was the new trend toward divergence between the central and local governments. With regard to these trends, under the influence of globalization and information technology progress, the speed and scope of industrial changes increased rapidly, and the operating performance of private enterprises improved. As a result, central governments' management and planning ability with regard to industrial flow decreased dramatically, while the role of local governments in attracting investments and promoting economic development became more important. However, planning, administrative coordination, and system-related problems emerged, drawing growing attention to cross-boundary issues. The effects of the described trends reflected the centralization of national welfare states and their gradual orientation toward transnational and decentralized forms. Therefore, city governance and spatial policy coordination were faced with such challenges as system breakdowns, union diversification, and complications in the spatial distribution 
of socio-economic activities. Moreover, an in-depth analysis of the inner dynamics of urban areas revealed contradictions and issues in the system and spatial development of urban areas. With regard to the system aspect, on one hand, the increased local accountability, responsiveness, and inter-city conflicts within one state resulting from governmental administration transfers, substantial differences, and injustice in socio-economic conditions in urban areas have hindered cooperation between city governments. On the other hand, the increased international economic competition has increased the importance of regional coordination and cooperation (Lee, 2017).

Figure 2 demonstrates the background behind the development of city governance and coordination strategies described above.

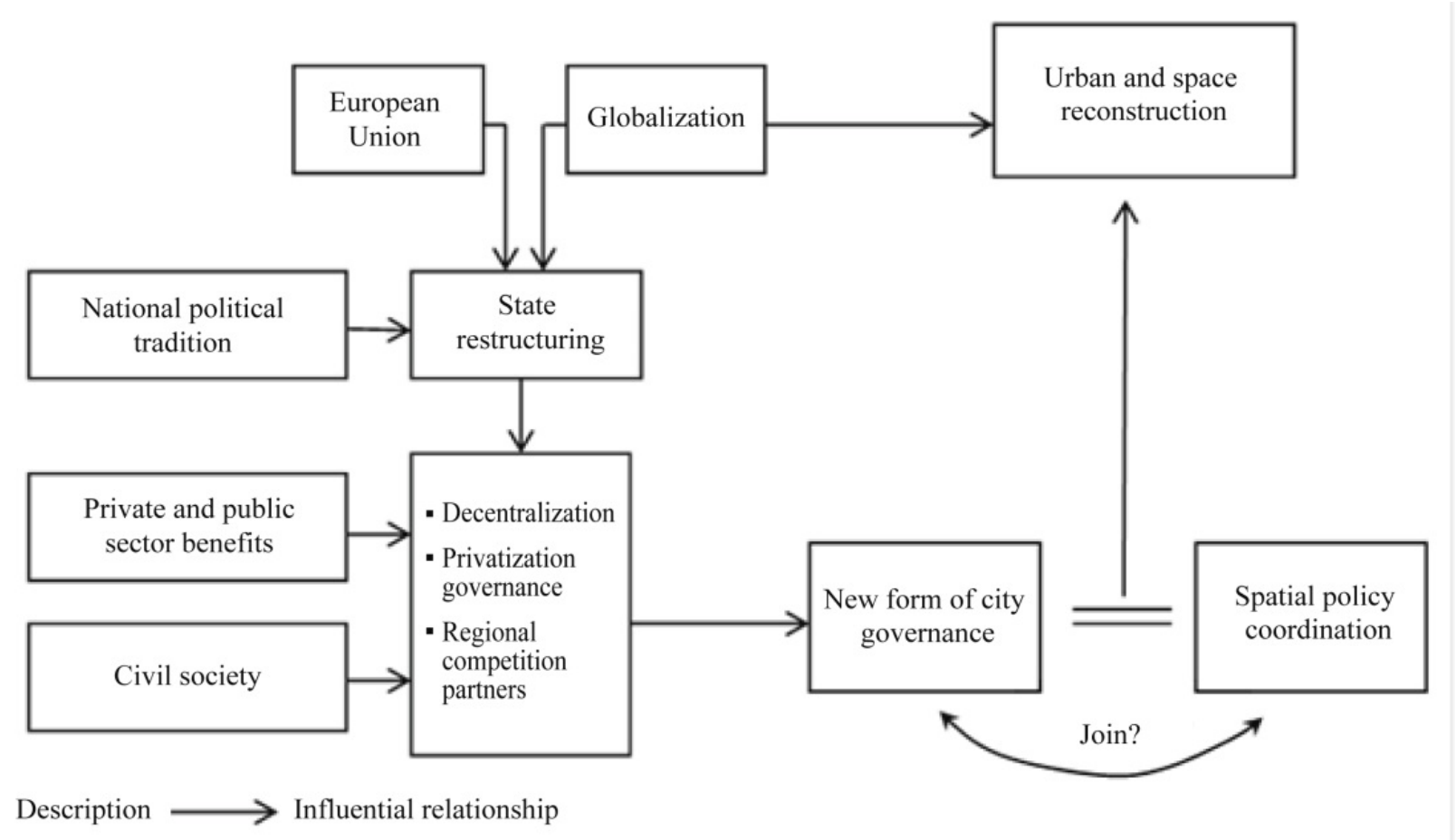

Figure 2. Formative factors of city governance. Data source: Compiled by this study.

As shown in Figure 2, driven by the trends and influences of globalization and regional economic integration, local governments in all countries have actively improved their competitiveness in order to gain a strategic position in regional development. As a result, the roles and functions of local governments have changed. However, a consensus has not yet been reached regarding how the new form of city governance and spatial policies should be coordinated. Studies on the issue of urban cooperation governance have discussed the discrepancy between city functional areas and local government structure. With regard to the coordination of the new form of city governance and spatial policy, studies on the issue of urban cooperation governance have discussed the discrepancy between city functional areas and local government structure. This long-term debate about city governance models gave rise to lively discussions in the second half of the twentieth century due to the interactional influences of traditional reformist and public choice theories (Wang, 2016a). The "new regionalism" movement formed in city governance in the 1990s was a product of dialogues between traditional reformists and public choice supporters. New regionalism proposes that both competition and cooperation must 
be implemented when addressing the issue of city governance in order to achieve affective governance of urban areas and establish local strategic partnerships. Such partnerships involve cooperation and collaboration with respect to city governance. In new regionalism, cooperation and collaboration are in a mutually strengthening relationship. Collaboration-guided cooperation facilitates the establishment of collaboration and cooperation. Regardless of the city governance form, three common objectives are pursued: (a) Urban areas combine formal and informal methods to improve cooperation between local governments. Mutual collaboration and cooperation increases urban areas' competitiveness within the global economic system. (b) Negative external issues not controlled due to jurisdictional fragmentation are managed through urban governance institutions. (c) Newly established city governance institutions provide public finances and tax reduction to promote the development of city centers, reducing the gap between city centers and suburban development and allowing for the more effective development of the regional economy. Studies on community authority first appeared in the 1950s and gained momentum in the 1960s. The main implication of research on community authority was in providing a platform for research on city and state politics and economies and establishing examples and theoretical bases for future research on urban politics and economies through pluralism and elitism-related debates and studies (Wang, 2005; Wu, 2017). Due to the development of neo-Marxist and neo-Weberian Theory in later years, some studies on community authority changed their focus to policy research, which, for example, included the Growth Machine Theory from the 1970s and city government theories form the 1980s. This study analyzed studies and theories related to city governance and proposed the use of the city governance development framework based on the core concepts of city governance as the principal axis of the PPPs model. The core concepts of city governance are outlined in Figure 3.

The term PPP refers to partnership relations established between public and private sectors to provide public goods. When governmental resources are limited, a PPP effectively enables the utilization of governmental funds by integrating the Build Operate Transfer (BOT) model mechanism and increasing the financial benefits and resource integration for private enterprises participating in infrastructure. Due to national and local differences in practice, a widely accepted definition of PPPs has yet to be developed. The following are PPPs definitions summarized in the Report on China PPPs Research with Reference to Global and Britain PPPs Development from October 31, 2017: (1) World Bank: PPPs refer to long-term contracts between the government and private sector, "for providing a public asset or service, in which the private party bears a certain level of risk and management responsibility, and its remuneration is linked to performance". (2) The United Nations Institute for Training and Research: PPPs cover all institutionalized cooperation between different social system advocates, and are aimed at solving complex local issues. PPPs exist at two levels. First, they include cooperation relationships established between public and private advocates to meet the demand for public products. Second, they include the implementation of large-scale public projects aimed at the establishment of partnerships between the public and private sectors in order to meet the demand for public products. (3) European Commission: PPPs refer to partnerships between the public and private sectors that cooperate in order to execute projects that are traditionally executed by the public sector or provide services that are traditionally provided by the public sector. A PPP recognizes that both parties each possess their own advantages. As each party performs work that it excels at, public services and infrastructure are provided using the most optimal methods. (4) The Canadian Council for Private-Public Partnerships: A PPP is "a cooperative venture between the public and private sectors that is built on the expertise of each partner and best meets clearly defined public needs through the appropriate allocation of resources, risks and rewards." (5) US 
National Council for Private-Public Partnerships: A PPP is a public product provision method that is situated between outsourcing and privatization and combines characteristics of both. A PPPs uses private resources to design, establish, invest in, operate, and maintain public infrastructure and deliver related services to meet the public demand. (6) Her Majesty's Treasury: PPPs refer to projects executed based on cooperation between the public and private sectors. In their broad definition, PPPs include cooperation between independent operations of the public and private sectors aimed at the implementation of policies, delivery of services, and construction of infrastructure. (7) Ministry of Finance of the People's Republic of China: PPPs refer to long-term cooperation relationships established in the fields of infrastructure and public service. Traditionally, social capital is used in most operations involving the design, establishment, operation, and maintenance of infrastructure, while reasonable return on investment is obtained through the "user pays" and "government pays" models. To maximize public interest, the government is responsible for prices and quality control of infrastructure and public services.

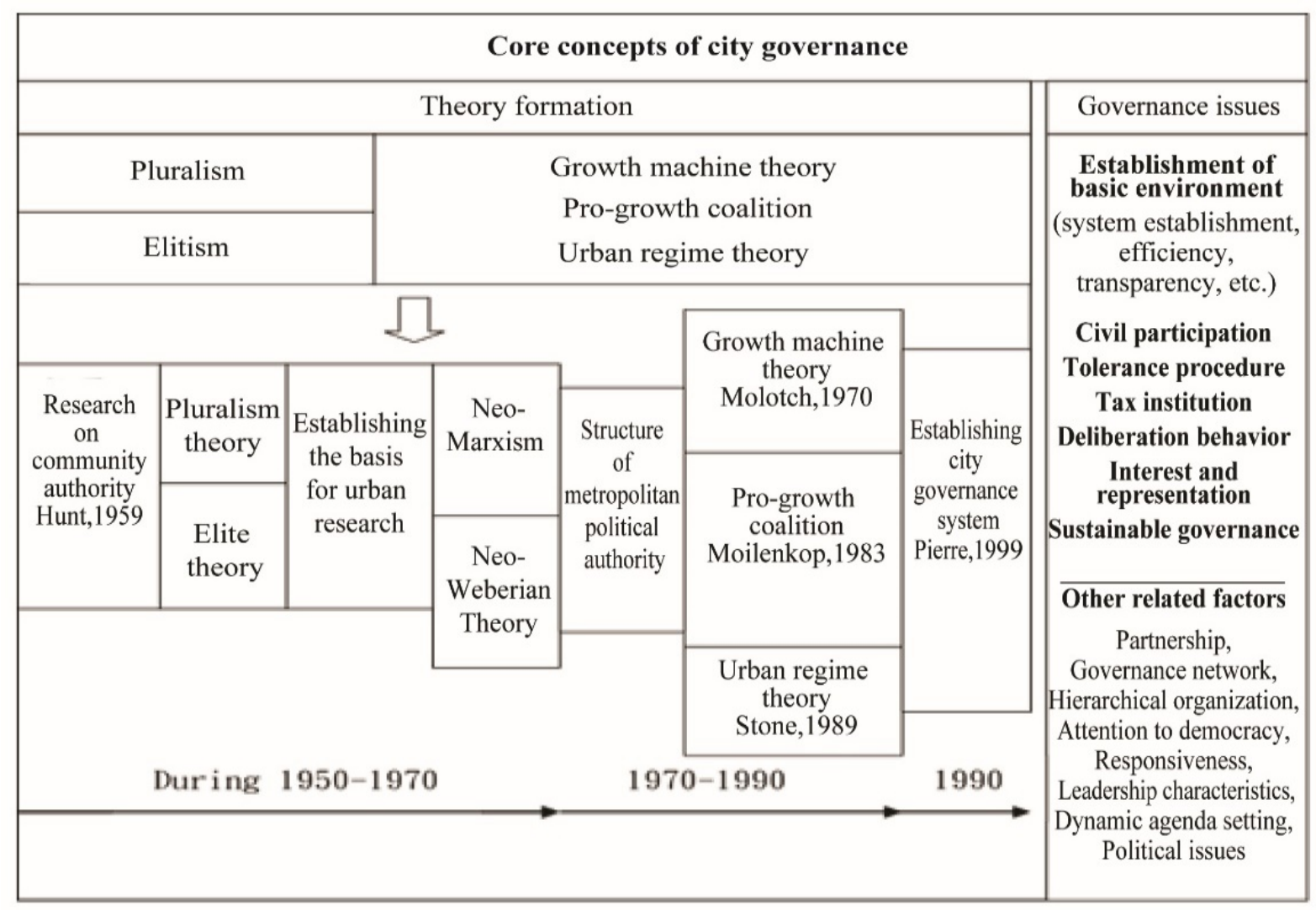

Figure 3. Core concepts of city governance. Data source: Compiled by this study.

The PPPs concept is frequently used in many United Nations and European Union documents. In view of the widespread use of the BOT model globally, it can be said that the BOT concept, in a narrow sense, is also being used by developed countries, particularly those in Europe (2017).

Summary: In summary, PPP is an abbreviation of "public-private partnership". The UK was the pioneer of general partnership, and in 1992, the British government led by John Major became the first to introduce a PPP project. In 1997, Tony Blair's government continued to promote PFI. The focus of governance shifted from 
restrained procurement costs to risk sharing between public and private sectors and improved service quality. China's promotion of its One Belt, One Road initiative has led to a global upsurge of the PPP model. The PPP model refers to a model of cooperation between public sector (government) and private enterprises in the field of public construction. The appropriate and effective implementation of PPPs can stimulate infrastructure development and promote and maintain economic growth. In addition to the commonly used BOT indicated that apart from financial considerations, another characteristic of the BOT model is the principle of risk sharing between public and private sectors. Essentially, the BOT model is a risk-sharing partnership. The government and investors are inevitably faced with various risks during the planning and implementation of a BOT project, including moral hazard risks, commercial risks, economic risks, and political risks. Most urban development strategies currently used by advanced countries in large cities no longer use the economic value of land development as the basis for measurements. Strategies of sustainable urban development are founded upon the balance between ecology, production, and livelihood. Furthermore, professional research and practices are integrated in the process of strategy formulation and communication.

\section{Methodology}

A popular and helpful categorization separates qualitative methods into five groups: ethnography, narrative, phenomenological, grounded theory, and case study. John Creswell outlines these five methods in Qualitative Inquiry and Research Design. While the five methods generally use similar data collection techniques (observation, interviews, and reviewing text), the purpose of the study differentiates them-something similar with different types of usability tests. And like classifying different usability studies, the differences between the methods can be a bit blurry. Here are the five qualitative methods in more detail.

(1) Ethnography. Ethnographic research is probably the most familiar and applicable type of qualitative method to UX professionals. In ethnography, you immerse yourself in the target participants' environment to understand the goals, cultures, challenges, motivations, and themes that emerge. Ethnography has its roots in cultural anthropology where researchers immerse themselves within a culture, often for years! Rather than relying on interviews or surveys, you experience the environment first hand, and sometimes as a "participant observer".

(2) Narrative. The narrative approach weaves together a sequence of events, usually from just one or two individuals to form a cohesive story. You conduct in-depth interviews, read documents, and look for themes; in other words, how does an individual story illustrate the larger life influences that created it? Often interviews are conducted over weeks, months, or even years, but the final narrative doesn't need to be in chronological order. Rather it can be presented as a story (or narrative) with themes, and can reconcile conflicting stories and highlight tensions and challenges which can be opportunities for innovation.

(3) Phenomenological. When you want to describe an event, activity, or phenomenon, the aptly named phenomenological study is an appropriate qualitative method. In a phenomenological study, you use a combination of methods, such as conducting interviews, reading documents, watching videos, or visiting places and events, to understand the meaning participants place on whatever's being examined. You rely on the participants' own perspectives to provide insight into their motivations.

(4) Grounded theory. Whereas a phenomenological study looks to describe the essence of an activity or event, grounded theory looks to provide an explanation or theory behind the events. You use primarily interviews and existing documents to build a theory based on the data. You go through a series of open and 
axial coding techniques to identify themes and build the theory. Sample sizes are often also larger-between 20 to 60 - with these studies to better establish a theory. Grounded theory can help inform design decisions by better understanding how a community of users currently use a product or perform tasks.

(5) Case study. Made famous by the Harvard Business School, even mainly quantitative researchers can relate to the value of the case study in explaining an organization, entity, company, or event. A case study involves a deep understanding through multiple types of data sources. Case studies can be explanatory, exploratory, or describing an event.

This study has chosen the case study research method as the theoretical framework for the qualitative data collection and analysis, to explain its guiding principles and show how this study hopes to apply these principles to research question. The case study has been especially used in social science, psychology, anthropology and ecology. Basically, a case study is an in-depth study of a particular situation rather than a sweeping statistical survey. It is a method used to narrow down a very broad field of research into one easily researchable topic.

Whilst it will not answer a question completely, it will give some indications and allow further elaboration and hypothesis creation on a subject. The case study research design is also useful for testing whether scientific theories and models actually work in the real world. It mithgt come out with a great computer model for describing how the ecosystem of a rock pool works but it is only by trying it out on a real life pool that we could see if it is a realistic simulation.

For psychologists, anthropologists, and social scientists, they have been regarded as a valid method of research for many years. Scientists are sometimes guilty of becoming bogged down in the general picture and it is sometimes important to understand specific cases and ensure a more holistic approach to research.

\section{Regional Background and Implications of This Study}

City development trends with the rise of environmental awareness in the 1990s, planning systems increasingly attached more importance to the overall interactions between human, resources, the environment, and development. Under the influence of the sustainable development concept and the prerequisites of limited natural resources and unlimited human wants and needs, plans should include an appropriate level of control over the rational use of natural resources in order to achieve sustainable development. Moreover, due to global trends, countries no longer pursue national and private economic profits blindly. The world economy has entered the resource integration phase involving international cooperation and regional development. With regard to performance enhancement, both the public and private sectors have realized that the establishment of a stable partnership relationship can improve the results of environmental and business management and construction development. Therefore, it is necessary to strengthen civil participation and PPPs. With the global shift toward globalization and delayering, cities have become nodes in the global network. In addition to its key role in regional competition, city development has gradually expanded beyond national boundaries, and has become as important as the general planning of the state.

Many examples of cities worldwide indicate changes in city regeneration trends. The focus has switched from a large-scale base development plan to overall city revitalization, from environmental reconstruction to redevelopment and physical adjustment of the entire area, and from purely private development or governmental construction to diverse development models and partnership relations. The main planning trends that reemerged in the 2000s included "green", "participatory", "regionalist", "regulatory", and "redistributive". 
New planning formats were gradually developed, based on concepts as such environmental awareness, sustainable development, ecological conservation, civil participation, and economic integration (concepts related to regionalism and regional union economy).

Modern urban revitalization strategies search not for the ways to build beautiful and magnificent landmark buildings but for the ways to build comfortable high-quality residential facilities. Their objective is to create an environmental that promotes creative lifestyle and production. However, a review of the history of Taiwan (Table 1) with respect to urban revitalization changes reveals that at all stages of development, Taipei City was restricted by the modernism approach to urban renewal.

Table 1

Analysis of the Neoliberal City Development Concept

\begin{tabular}{|c|c|c|c|}
\hline $\begin{array}{l}\text { Main steps of } \\
\text { Taipei } \\
\text { globalization }\end{array}$ & $\begin{array}{l}\text { Developmental } \\
\text { state } \\
\text { managerialism }\end{array}$ & Transformation period & $\begin{array}{l}\text { Developmental state } \\
\text { entrepreneurialism }\end{array}$ \\
\hline Transition period & 1960 & 1980 mid-1980s & 1990 mid-1990s 200020102020 \\
\hline $\begin{array}{l}\text { Characteristics of } \\
\text { Taiwan's } \\
\text { economy }\end{array}$ & Industrialization & $\begin{array}{l}\text { Transformation period } \\
\text { Capital export country } \\
\text { Post-industrialization change }\end{array}$ & \\
\hline $\begin{array}{l}\text { Liberalization } \\
\text { policies in the } \\
\text { country }\end{array}$ & & $\begin{array}{l}\text { Martial law end/democratization (1987) } \\
\text { Financial liberalization (1989) } \\
\text { Approval of new bank establishment (1991) }\end{array}$ & $\begin{array}{l}\text { Taipei mayoral election (1994) } \\
\text { Civil participation in public } \\
\text { construction (1994) } \\
\text { China Steel privatization (1995) } \\
\text { Chang Hwa Bank privatization } \\
\text { (1988) } \\
\text { Taiwan Fertilizer privatization } \\
\text { (1999) } \\
\text { National land privatization (2000) }\end{array}$ \\
\hline $\begin{array}{l}\text { Important } \\
\text { development } \\
\text { directions } \\
\end{array}$ & Xinyi Fuduxin & $\begin{array}{l}\text { International trade center } \\
\text { Economy and trade area }\end{array}$ & $\begin{array}{l}\text { High technology factory } \\
\text { Central station }\end{array}$ \\
\hline City formation & $\begin{array}{l}\text { Industrial city } \\
\text { Dual core }\end{array}$ & $\begin{array}{l}\text { Consumer city } \\
\text { Dual core }\end{array}$ & $\begin{array}{l}\text { Post-industrial city } \\
\text { Urban renewal (1998) } \\
\text { Multi-core development }\end{array}$ \\
\hline $\begin{array}{l}\text { City governance } \\
\text { and politics }\end{array}$ & $\begin{array}{l}\text { State-led: } \\
\text { Economic and } \\
\text { general } \\
\text { development }\end{array}$ & $\begin{array}{l}\text { State led: Major construction and planning } \\
\text { Local-led: Development adjusted to the policies of the } \\
\text { central government }\end{array}$ & $\begin{array}{l}\text { Local-led: Company merging } \\
\text { The initial focus was on active } \\
\text { development; subsequently, the } \\
\text { leading position was taken }\end{array}$ \\
\hline $\begin{array}{l}\text { Central } \\
\text { government role }\end{array}$ & Full control & $\begin{array}{l}\text { Regional development affected by deregulation and } \\
\text { privatization policies } \\
\text { Intention to promote economic development via real } \\
\text { estate development } \\
\text { Dominance over local development through development } \\
\text { of state-owned land }\end{array}$ & $\begin{array}{l}\text { Eased legal regulations to meet } \\
\text { needs of local land development } \\
\text { Participation in development of } \\
\text { local unions as landlords }\end{array}$ \\
\hline
\end{tabular}

Data source: Compiled by this study.

\section{Regional Background and Implications of This Study}

The regional background in this study was the metropolitan area of Taipei, the leading example of a metropolitan area in Taiwan. Cultivation of the land began over 300 years ago. Today, Taipei is a capital city and center of Chinese culture. Taipei has urban traits that many European and American cities lack and admire, such as convenience and diversity due to mixed land use, small business groups, multinational integration, etc. These characteristics give Taipei the image of diversity and enable the forming of amiable and tolerant relations 
between citizens. This is one of the city's hidden strengths and an important element that promotes city transformation and revitalization, breaking through the current urban development framework in view of rapid global changes. Thus, each area is unique in its own way. The planning and design of a city involves long-term development perspectives and transitions. Requirements with regard to city functions and content often change when time and space-related factors change. The construction and operation of a city environment by following various design guidelines and approval procedures has become an inevitable trend. The four major projects and important procedures of metropolitan area development in Taipei are shown in Figure 4.

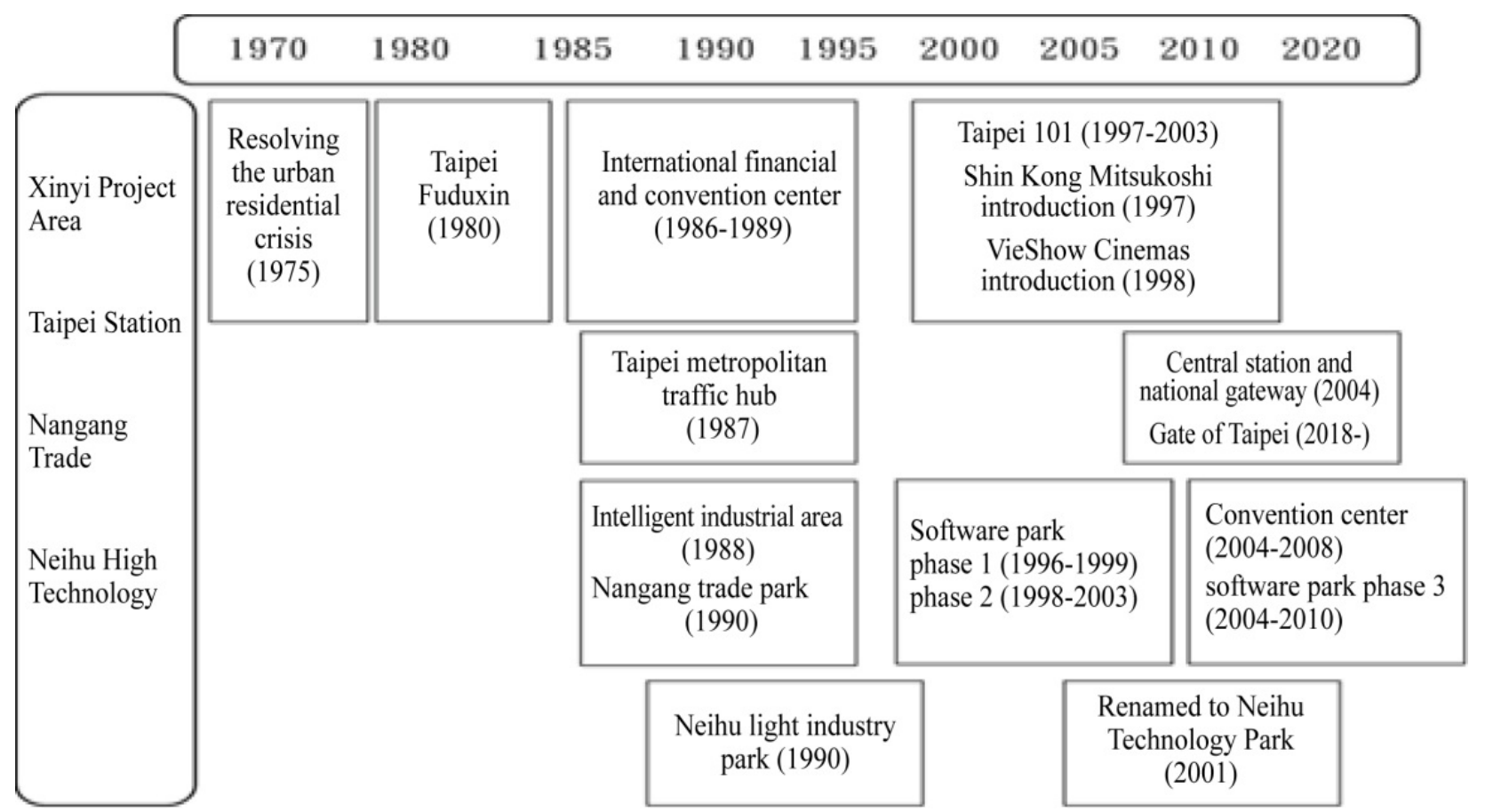

Figure 4. Four major projects and important procedures of metropolitan area development in Taipei. Data source: Compiled by this study.

\section{Case Study and Practical Arguments}

\section{Summary of Basic Urban Development Plan Under the Taipei Central Bus Station BOT Project}

Taipei has long been the core development city of Taiwan. Based on the objectives listed in the White Paper issued by the Taipei City Government, "Outlook on an Enjoyable and Livable Ecological Capital", urban space development in Taipei will be oriented toward the provision of human space. In addition to being Taiwan's intercity gateway, the Taipei Main Station special zone will be upgraded to an international gateway after Taiwan's Taoyuan International Airport and Taipei Main Station are linked via its Mass Rapid Transit (MRT) system. The Executive Yuan lists Taipei Main Station as a "National Gateway Plan" within the "Doubling Tourists Arrival Plan". Thus, under the global trends of urban development, the project of connecting Taiwan's Taoyuan International Airport to Taipei Main Station via MRT is implemented with the international gateway perspective in mind.

According to the "Main Plan of Taipei Main Station Special-use Zone" that was announced by the Taipei City Government in 1993 and the objectives of the main urban planning project, the following development points of Taipei Main Station can be distinguished: (1) Combine a high speed rail station, Taiwan Railway 
Station, long-distance bus station, MRT station, Taipei Central Bus Station BOT project of PPPs modle, public square, and parking lot to transform the area into the traffic hub of Taipei. (2) Promote the overall development of the Taipei Main Station area, provide continuous and diversified open space, and create a good city image and landscape. (3) Remodel the gateway to Taipei by drawing from the area's history. (4) Effectively use revitalized land after the implementation of the railway underground project to promote the redevelopment of the city center area and improve the city environment.

Consideration is given to the developmental points of the Taipei Main Station special-use zone, integration of the airport MRT station into the special-use zone, the $\mathrm{C} 1$ and D1 joint development buildings, and the construction of the airport underground terminal station, the BOT project for PPPs modle for Taipei Bus station to completed the Taipei Central Station zone. The Taipei City Government invited an internationally-renowned architect, Fumihiko Maki, and J.J. Pan and Partners, Architects \& Planners to participate in the Detailed Design Consultants and China Engineering Consultants Incorporated team and develop a farsighted overall design for city development that would compliment the surrounding areas' development. The team was to propose urban design concepts that take into account the links between various transportation systems and public spaces. The redevelopment of the Taipei Main Station special-use zone was promoted in order to establish the capital's central gateway and build the international image of Taipei.

(1) Site environment and superior position plan. The Taipei Main Station special-use zone includes the eastern part of Huanhe South Road, the southern part of Huayin Street (including the Turn of nine precincts), the northern part of Zhongxiao Road, and the western part of Zhongshan North Road. The area circle includes the Dr. Sun Yat-Sen Memorial House and parks No. 1 (Taipei Main Station), 4, 5, 6, 7, 8, 10, 12, C1, D1, E1, $\mathrm{E} 2$, and 13. It is one of the first areas to be developed in Taipei and contains rich historical and cultural resources. After the implementation of the railway underground project, the Taipei Main Station special-use zone urban planning project was approved by the Urban Planning Committee, Ministry of Interior, in 1990. The Urban Planning Division of the Public Works Department, Taipei City Government, commissioned the design and planning of the Taipei Main Station special-use zone by Sasaki Associates. In 1993, the details of the Taipei Main Station special-use zone planning project were announced. To date, no actual construction has been carried out. The station is located in a prime location in Taipei and has such advantages as historical resources, solid commercial foundation, and traffic hub position. Therefore, related development projects focus on cultural preservation, communication construction, recovery of local industries, and landscape improvement. The most important construction project among them is the "Central Station and Central Park Overall Planning and Design Project" that involves the entire area and will determine urban development in the next 10 years. The scope of planning under this project includes the Taipei Main Station special-use zone (from Tamsui River to Zhongshan North Road), the Huashan urban planning area (from Zhongshan North Road to Xinsheng North Road), and a 30-meter area along Zhongxiao Road and the Civic Boulevard. The objective is to reexamine the position of the train station special-use zone, create a new image of the gateway, integrate transportation systems, plan communication paths for each surface (both above and underground), review the overall city plan and develop a financial plan in order to improve the traffic environment and shape the central station and central park. The "Central Station and Central Park Overall Planning and Design Project" is shown in Figure 5. The development of the western part of Taipei Main Station area focuses on improving the life circle within Taiwan after completion of HSR and airport MRT line and Taipei Bus station to creating Taipei pass. In order to execute this transportation plan and accommodate the links between the various systems and modes of 
transportation found around the station and in the underground passes nearby, and thereby create a Taipei pass, major adjustments are required. Historical sites in the North Gate area include the North Gate, old machinery housing from Qing Dynasty, former site of the Ministry of Railway, and Taipei post office. A themed museum will be established to reproduce local historical sites. In the Executive Yuan area which stretches from the eastern end of Zhongshan North Road to Linsen North Road, a safety management system will be applied to develop green space for public use. Huashan Creative Park and Syntrend Creative Park that present multimedia culture combining high-technology and information industries and creative arts will be extended and merged with surrounding urban activities. In the dynamic line linking different areas, eco-oriented open spaces will be established, including ponds and forest. Buildings will be linked via tunnels and two-floor overpass systems. A friendly walking environment on the main path will be provided through commercial facilities and moving walkways.

At the North Gate Plaza opening ceremony held on August 3, 2017, Taipei mayor Ko Wen-je announced the completion of the West Gate plan and recovery of the historical value of the North Gate. It was emphasized that, while Paris has the Arc de Triomphe, Taipei has North Gate. North Gate may become a new landmark of Taipei and a symbol of Taiwan's national gate. The slogan "Changing Taiwan, starting with the capital; changing Taipei, starting with its culture" was declared, with North Gate restoration being the starting point of the restoration of forgotten human culture, history, and glory.

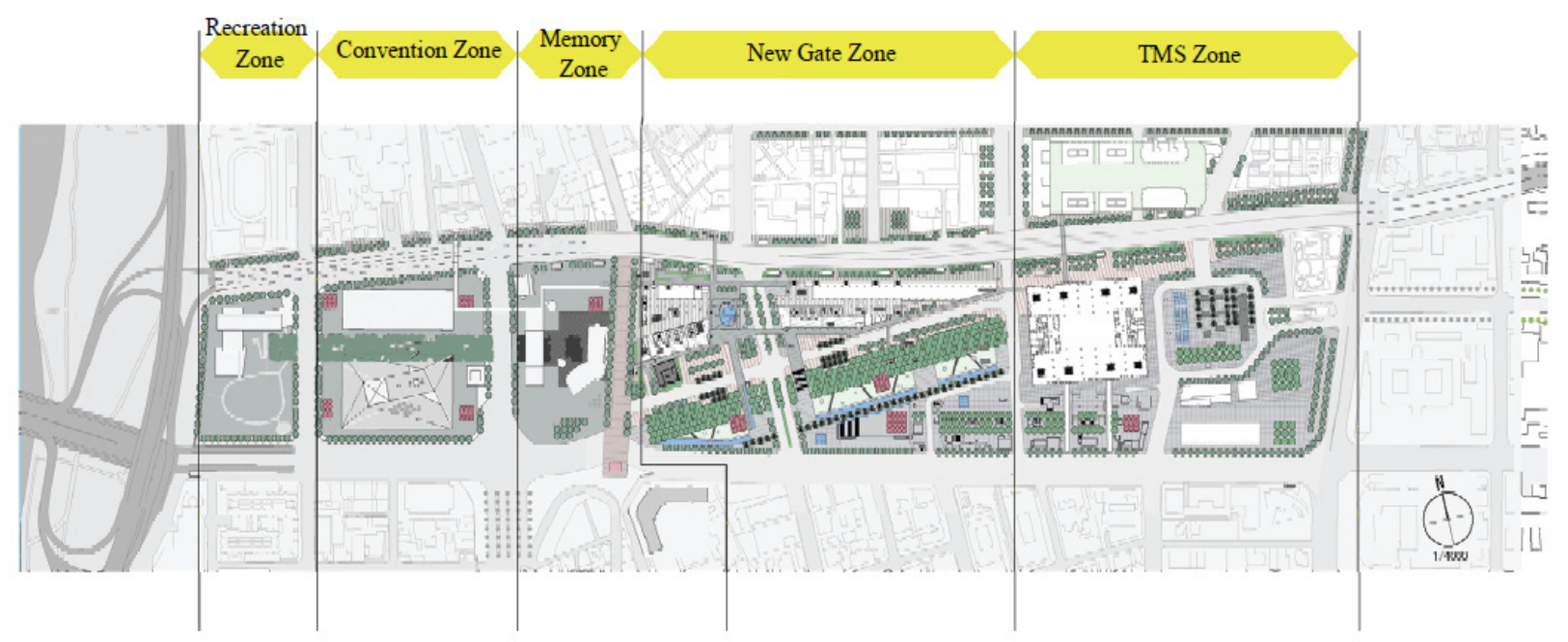

Figure 5. Central station and central park overall planning and design project. Data source: Department of Urban Development, Taipei City Government (2008), Taipei City Government Secretariat (2017).

(2) Plan of establishing an MRT connection between Taoyuan International Airport, Taipei, and Sanchong. The connection of Taoyuan International Airport to the MRT system initially involved the integration of an elevated line into Taipei Main Station special-use area and construction of an elevated station in the northern part of Taipei Main Station. However, based on planning considerations regarding this area as the future gateway of Taipei, it was suggested that the elevation method may negatively affect the city landscape, historical preservation, and open space maintenance. The planners then decided to use an underground tunnel in the Taipei Main Station section of the airport-Taipei-Sanzhong MRT connection. The tunnel will go along the southern part of the Civil Boulevard through Yuquan Park, cross Xining North Road and E1 base and proceed 
to the east after Beimen Station (G14) on the Songshan MRT line; it will cross D1 west base (D2) and D1 east base (D1), ending at C1 zone in the western part of Taipei Main Station. The Taipei Main Station portion of the airport MRT line will be established on two floors above ground and three floors underground. Apart from the station, Joint Developmental Buildings will be constructed at C1/D1 in order to promote the development and utilization of surrounding lands and create a new national gateway. Private land owners will benefit from the land development value created by MRT facilities. With regard to the government, the benefits of land development enabled by the Joint Developmental Buildings will effectively attract private capital and balance expenses of public works.

(3) The overall concept design of the Joint Developmental Buildings and the Taipei Main Station special-use zone. It is hoped that comprehensive urban development strategies and design will be proposed using transportation reform, financial planning, city administration, and spatial design. Urban design concepts are to be proposed in consideration of the link between the various transportation systems and the public spaces and historical resources of the community. The redevelopment of the Taipei Main Station special-use zone is promoted in order to establish the capital's central gateway and promote the international image of Taipei.

(4) The objectives for the comprehensive development of the Taipei Main Station special-use zone are as follows.

I. Recreate the capital appearance and strengthen the national gateway image: Overall development of $\mathrm{C} 1$ and D1 and overall planning of the A1 station will be performed to shape the national gateway image, create the city landmark and improve urban landscape.

II. Promote surrounding land use and establish forward-looking city development: The A1 station will be expanded to include Taoyuan International Airport service functions. It is planned to introduce international finances, aviation, merchandise, and tourism to increase international competitiveness of Taipei and promote utilization of surrounding lands.

III. Improve functions of Taipei traffic hub: Public transportation systems, such as MRT, railway, HSR, long-distance bus, and airport MRT, within the station special-use zone will be planned to address transportation bottlenecks in the zone and improve functions of Taipei traffic hub.

(5) Key issues and strategies of regional planning. The Taipei Main Station special-use zone was one of the first areas to be developed in Taipei. Earlier, no developments could be performed in the area due to railways. City activities were split by railroads into the station front and station back. However, after the implementation of the railway underground project and the release of a large number of new plots, the zone was seen as the "eternal" construction site of Taipei due to shifts in city development focus and the lack of agreement between governmental agencies and landlords with regard to the area's development, and public lands were left idle. Currently, the area is undergoing large-scale public works due to the airport MRT, and the existing space can potentially be fully utilized. The western part of Taipei Main Station is developed toward a special-use zone involving Taoyuan International Airport service functions. There are plans to introduce international finances, aviation, merchandise, and tourism to promote the area's afforestation, integrate surrounding historical assets and promote the development of the western part of Taipei.

\section{This project combines Taipei's past with its future opportunities}

The following are related key issues and strategies:

(1) Create a public green system and maintain the diversity of urban activities. With the industrial advances in Taiwan and its national urbanization, Taipei has been experiencing an inflow of people. Thus, 
diverse transportation transfers were organized to ensure concentrated use density. According to the 1996 White Paper on Taipei City Development, Taiwan ranked last among advanced countries in terms of the scale of park use by Taipei residents (New York-13.95 $\mathrm{m}^{2}$; Paris-12.7 $\mathrm{m}^{2}$; Seoul $-8.7 \mathrm{~m}^{2}$; Tokyo $-4.7 \mathrm{~m}^{2}$; Taipei $-2.5 \mathrm{~m}^{2}$ ). Therefore, the creation of useful green space in the process of urban renewal has become a pressing issue. Following the example of New York's Central Park, construction of a central station within central park is planned. Green space will cover the area from Tamsui River to Taipei city center, while maintaining city activities in the surrounding areas. The "city's green axis" design concept will link economic activities, traffic lines, and historical site reutilization to create urban spaces that honor history, while meeting needs and increasing land use value. With regard to space, in addition to transportation facilities and historical sites, information industries, convention venues, and international trade services will be integrated in order to encourage regional development. A 1.6-kilometer long area between Tamsui River in the west and Zhongshan North Road in the east is divided into five zones by south-north roads, including, from west to east, the Recreation Zone, Convention Zone, Memory Zone, New Gate Zone, and TMS Zone. The arrangement of the five zones is determined by the axes of the Linear Forest and Taipei Skyway. Figure 5 shows the main spatial framework and main pedestrian paths that could viewe the five zones of the Taipei Main Station special-use zone and the city's green axis. Some linear parks connect S1 and D1 streets with the surrounding park system, strengthening the street axis system and expanding the human landscape system from east to west and from south to north within the development area. As such, trends for sustainable city development and planning strategies for an ecosystem are formed.

(2) Create a distinct image of national gateway. With changes in Taipei's fengshui hierarchical structure, the axis of Taipei's urban fabric has faced north, while its other axis has moved to Taipei's old city walls on the side of Qixing Mountain. Due to the station special-use zone's location at the intersection of the two axes and a 16.5 degree difference between the axes, the base zone has been seen as the visual end of roads. On June 18, 1875, Shen Baozhen asked for permission to establish a Taipei prefecture with one capital and three counties. In February 1875, construction of a magistrate in Taipei Mengjia, was approved with the continued inclusion of Taiwan within the military defense circuit. The three counties of the Taipei prefecture included Tamsui County, Hsinchu County, and Yilan County. In the 10th year of the Guangxu period (1884), under the long-term guidance of government officials and with the support of the local gentry, the Taipei prefecture zone between Monga (currently Wanhua District) and Twatutia was officially established. The North Gate was one of the five gates of the city and considered the main gate of Taipei prefecture. Facing north, the North Gate, also called Cheng-En Gate, received its name from "receiving emperor's kindness" and was the main passage to Twatutia in the earlier years. The gate is two floors high and its gate tower was surrounded by thick wall that formed a strong fortress. Square and round windows were left in the back and front to facilitate defense operations. Taipei North Gate has remained the only Taipei gate that was built during the Qing dynasty.

\section{Basic planning implications of the Taipei Central Bus Station BOT project}

Civil participation is encouraged in public works related to the Taipei Main Station special-use zone in order to strengthen the functions of Taipei's long-distance buses, MRT system, and railway transportation. Furthermore, the implementation of the Taipei Main Station special-use zone renewal plan is being accelerated. The government has provided a total of 21,374 square meters of land in the northern part of Taipei Main Station for development operations, including Chengde Road, Civil Boulevard, Gongyuan Road (Tamsui-Xinyi 
line of MRT), and Huayin Street (Turn of nine precincts according to the city plan). Private organizations are invited to participate in public bidding and selection of investors to develop and operate the Taipei Main Station special-use zone and the Taipei Central Bus Station BOT project of nine precincts land use (i.e. "Turn of Nine Precincts BOT Project"). State-owned land accounts for $54.77 \%$ of the Turn of nine precincts land (managed by Taiwan Railways Administration), while $45.23 \%$ of land use rights belong to Taipei (managed by the Department of Transportation, Taipei City Government). In the city plan "Transfer Station Land Use", the building coverage area is $80 \%$ and the capacity rate is $560 \%$. Municipal JianCheng Junior High School and East Building were originally built for use by traffic control centers of Taipei Rapid Transit Corporation and Taipei City Government Department of Transportation. Following the bidding winner's plan, 32 platforms and 16 bus parking lots were built at the transfer station. The area combined department stores, hotels, residence, and offices. Works were launched in June 2005 and completed in 2008.

As the Taipei Central Bus Station BOT project of nine precincts plan combines transfer station, residence, hotel, office building, and department store functions, the estimated annual income from commercial space rental reaches NT\$500 million. The position of a traffic hub for Taoyuan International Airport MRT is expected to reflect the strengths of important transportation gateway projects of Executive Yuan and integration of Taipei Main Station neighborhood urban renewal projects. The station is expected to become the "heart of Taipei" and promote balanced development of eastern and western districts. With regard to the shopping center, investors assigned a famous US designer team to bring in more diversity (compared to Taipei 101), focusing on domestic and overseas premium goods. At the same time, residential needs are met and a market is planned. At the opening ceremony, the shopping center is expected to attract $50,000-60,000$ people on a daily basis and three times more during holidays.

\section{Assessment of Turn of nine precincts land use efficiency and practical arguments}

PPPs model used in the Taipei Central Station project of Taipei Central Bus Station BOT Development Project provides Taipei citizens with the convenience of five co-constructed communications means. Moreover, the Taipei Main Station Special-use Zone Project adds value to neighboring lands and promotes the balanced development of eastern and western districts of Taipei. In order to reduce disproportion in development of eastern and western districts of Taipei and recover the past glory of old districts Datong and Wanhua, Taipei Government formulated special urban renewal plans addressing such issues as insufficient space in old city districts, chaotic traffic lines, and poor quality of living. The government aims to reconstruct key and landmark buildings and renovate transport infrastructure in order to remodel the city's landscape and attract people. Therefore, in Taoyuan International Airport MRT construction, the Taipei government plans to establish underground Taipei stations in the $\mathrm{C} 1$ and D1 areas of the Taipei Main Station special-use zone and to develop the $\mathrm{C} 1, \mathrm{D} 1$, and Turn of nine precincts. MRT system construction is promoted and urban lands are redeveloped and reused in order to improve city functions, enhance the living environment and increase the external economic benefits of land and buildings, which would mark a turning point in Taipei's development.

The PPPs model used in the Taipei Central Bus Station BOT Project has an important position in the overall development of Taipei. It is a public transfer center that links the railway, HSR, Taipei Metro, airport MRT, and bus systems. Opportunities and prosperity related to PPPs modle development of the Taipei Central Bus Station BOT project of nine precincts are determined by the attracted stream of people. The transfer station combines the airport operation model and smart transfer services. In addition to provision of intercity bus 
transportation at Taipei Main Station, bus companies compete in their service quality, providing passengers with a high-quality transportation environment. Apart from transfer station construction, the Turn of nine precincts development project also integrates the development of a shopping center, offices, international hotels, and housing. High-quality transportation conditions are created at the Turn of nine precincts in order to form a diversified living space combining traffic, commerce, offices, residence, and related facilities. Furthermore, the government also pays attention to promotion of a sustainable ecological environment and e-city, integrating green building concepts and open squares and green space to create a walking city underground and park city above ground is shown in Figure 6. As such, the Taipei Main Station special-use zone is formed into the "national gateway" and "heart of Taipei", marking a starting point in Taipei's development and construction based on internationalization, humanization, and sustainability.

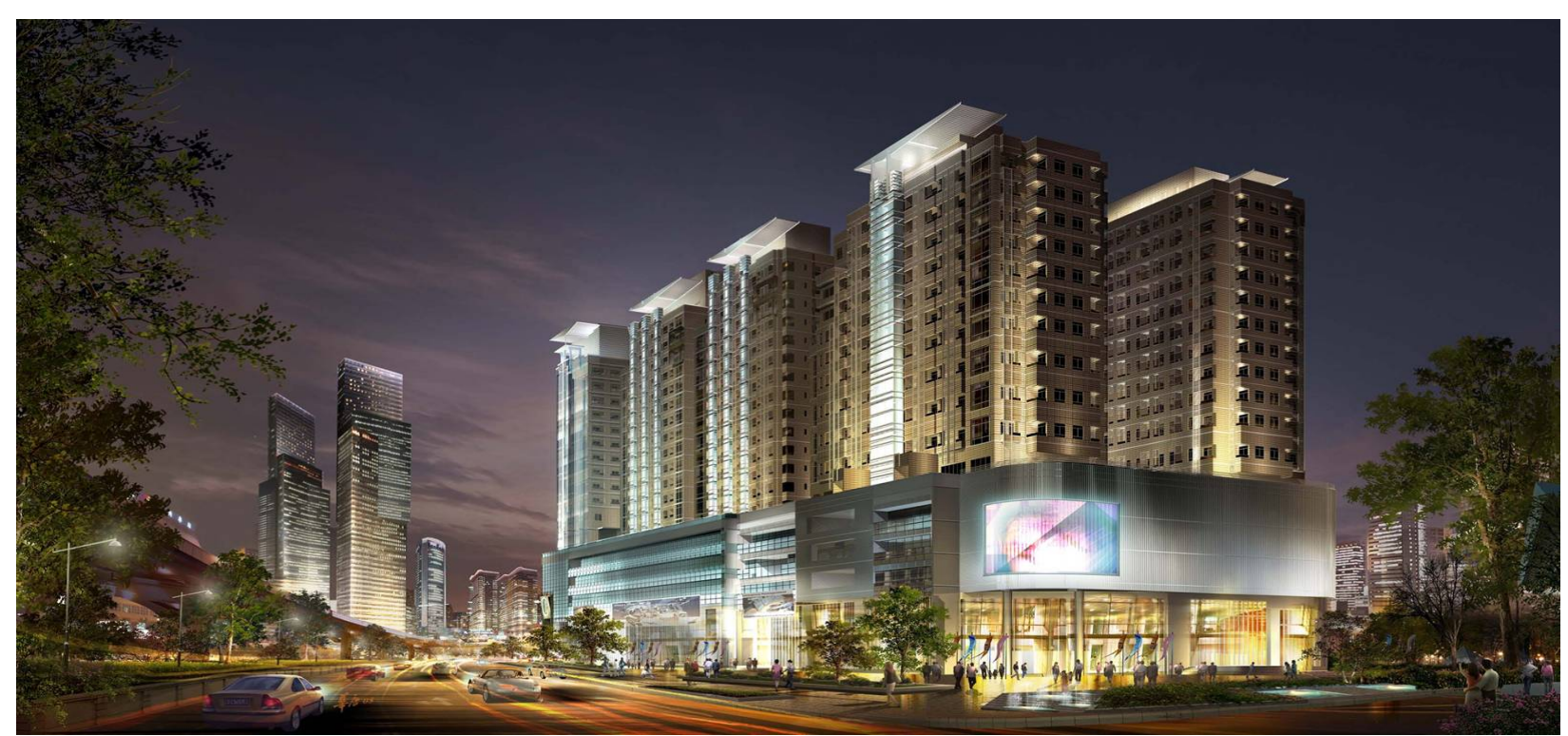

Figure 6. Taipei Central Bus Station BOT Projectformed into the "national gateway" and "heart of Taipei". Data source: Compiled by this study.

\section{Conclusion}

\section{Research Conclusions}

This study employed a neoliberalism-centered urban development approach and aimed to fulfil the economic demand for economic development and urban space transformation through the neoliberal urban development and city governance of Taipei. The following conclusions were made: (1) The basic goal of global city competitiveness of Taipei was promoted by implementing "qlubarnization", a spatial development strategy dependent on intercalary abilities. (2) Taipei is located in the hub of Asia, linking mainland China and Taiwan, facing the world, peaceful and stable, rich and diverse in culture, such that adopting the "hybrid or mixed-use development model" will allow "The national gate of the country program-Central Station, Central Park" to become an international city brand. (3) Taking the "Taipei Main Station Turn of PPPs modle development of the Taipei Central Bus Station BOT project of nine precincts specific land development projects" as a key success indicator, the government took privatization or PPP into consideration, loosened the monopoly on urban infrastructure, created infrastructure services and a maintenance market, positioned the city as a "supranational" entity in terms of capital flow, and sought a coherent land policy. 
A space planning system is an important factor in neoliberal urban development and city governance issues relating to regional social capital. Since the urban design and planning of the Taipei Main Station special-use zone conducted in 1990 by Sasaki Associates, the construction of an MRT section between Taoyuan International Airport and the Taipei Main Station special-use zone through the development of a comprehensive planning and design project for a central station and central park has also been planned. This study presents the main conclusions regarding leadership in public construction policies in previous years (government $90 \%$; private sector $10 \%$ ), which has changed due to the PPPs model applied nowadays (government 10\%; private sector $90 \%$ ). The further construction of the airport MRT is planned to connect airport MRT underground station (A1) and the $\mathrm{C} 1$ and D1 Joint Developmental Buildings, which would incorporate past experiences and future development opportunities.

The transformation of the Taipei Main Station special-use zone into the national gateway aims to solve long-term and complicated city image issues related to neighboring areas of Taipei Main Station through optimized visualization and proposes that development will occur from east to west along a green axis in order to build an ecological framework for a city park. This plan for the Taipei Main Station special-use zone echoes Taipei's history, modern axis, and city spine perspectives. Five zones are proposed in this urban design, including a Recreation Zone, Convention Zone, Memory Zone, New Gate Zone, and TMS Zone. Construction of the airport MRT station and C1 and D1 Joint Developmental Buildings is at the core of the New Gate Zone. $\mathrm{C} 1$ and D1-related six-precinct and eight-precinct squares will undergo afforestation in the form of city forest, which will be the largest green promenade in Taipei city center. Length of the green promenade may reach 200-350 meters, with 36-meter depth in south and north. The green promenade of these dimensions may be duplicated in Huashan Creative Park, which, in combination with the station's garden, will form a 3-kilometer Central Park area in Taipei city center. The evergreen Central Park will merge large-scale buildings and wide open space, intertwined transport connections and walking paths, reaching the objective of green city vision and urban development. The Department of Rapid Transit Systems, Taipei City Government, implements the design of the Taipei Main Station special-use zone using forward-looking and comprehensive concepts. In view of the PPPs model, the central station project can exceed its transportation function by considering areas within the train station. The renewal of areas neighboring the station can improve impressions of Taipei's city center, marking a large step in the city's internationalization. The past space planning system used in Taiwan did not involve regional metropolitan plan arrangement. The land project currently implemented by the central government integrates regional metropolitan plans into the official space plan. This study summarized conclusions regarding the policy's ability to bring positive effects to Taiwan's space planning system and ways to use regional metropolitan plans in Taiwan's space development and provided practical reference for related policy institutions.

\section{Research Contributions}

Gratitude is expressed to Professor Chun-Chang Lee, Professor Tsoyu Calvin Lin, Professor Che-Chun Lin, Professor Cheng-Yi Sun, and the supervising professor, Dr. Chien-Wen Peng, for making the completion of this study possible and to all professional consultant companies and governmental department directors and colleagues participating in the PPPs model for providing corrections and counseling. Four objectives were determined in this study through an analysis of advanced countries' experiences and scientific principles: (1) social equity; (2) economic competitiveness; (3) environmental protection; (4) financial (public works) 
efficiency, which are common requirements toward regional metropolitan planning in many advanced countries. Among the four objectives, equity can be subdivided into the guarantee of basic living rights and the improvement of social cohesion. Economic competitiveness can be subdivided into the creation of added value and the reduction of production costs. Environmental protection can be subdivided into ecological environment conservation and the improvement of living environment quality. Financial efficiency involves the reduction of costs of public works or services. These basic objectives can affect the content and methods of regional metropolitan planning. A new system of space governance is necessary to integrate these objectives into collective action. In view of increasing the international competitiveness of Taiwan, the implementation of regional metropolitan plans requires improvement of the regional ability to solve public issues, which particularly applies to the project involving the development of the Taipei Main Station special-use zone as the "national gateway". In this case, design directions include the improvement of regions' horizontal and vertical integration abilities and the arrangement of a solid system. These three directions can be summarized into one concept: reaching mutual accordance through the binding ability required to fulfil collective public interests and the force of personal pursuit of benefits.

\section{References}

Blinc, R., ZidanÓek, A., \& Òlaus, I. (2006). Sustainable development after Johannesburg and Iraq: The global situation and the cases of Slovenia and Croatia. Energy, 31, 2259-2268.

Boeuf, P. (2003). Public-private partnerhsips for transport infrastructure projects. Seminar on Transport Infrastructure Development for a Wider Europe, European Investment Bank, Paris, Nov. 27-28.

Borja, J., \& Castells, M. (1997). Local and global: Management of cities in the information age. London: Earthscan.

Brotchie, J., Batty, M., Blakely, E., Hall, P., \& Newton, P. (Eds.). (1995). Cities in competition: Productive and sustainable cities for the 21st century. Sydney: Longman Australia.

Chang, R. B. (2001). Globalization and localization considerations, innovation, and developments in urbanization and city management. Retrieved from http://www.stcsm.gov.cn/fuwuzhinan/fg/review/ref_report/

Chang, Y. C. (2001). Global governance under globalization: Subject and power analysis. International Conference of Global Governance and International Relations, Taipei.

Chen, Z. M. (2001). Subnational governments and foreign affairs. Beijing: Changzheng Publishing House.

Chiang, D. S., \& Chang, L. Y. (2016). Local governance: Changes, innovation, and practice. Baltimore, MD: Angle Publishing.

Chiang, M. C., \& Liu, K. Y. (1999). Entrepreneurial government: Theories, practices, and critiques. Best-Wise Publishing.

Chou, T. L., \& Hsing, W. C. (2001). Urban renewals in Taiwan and China. Hong Kong Journal of Social Sciences, 20, 131-161.

Clark, D. (1996). Urban world/global city. London: Routledge.

Finkelstein, L. S. (1995). What is global governance. Global Governance, 1(3), 367-372.

Gauzin-Muller, Dominique/Favet, Sustainable Architecture and Urbanism. (2002). Nicolas. Sustainable architecture and urbanism: Concepts, technologies, examples. San Francisco: Chronicle Books LLC.

Huang, Q. Y. (2007). A study on strategic construction planning implications. Master's thesis, National Cheng Kung University.

Huang, S. L. (2000). Sustainable cities and ecological land use planning. Taipei: Chan's Arc-Publishing.

Jan, C. Y. (2001). Globalization and reforming public administration: The reviews from the perspectives of knowledge-based economy. 2001 Conference of Knowledge Economy Society and National Development, Taipei, National Taiwan University.

Jessop, B. (1998). The rise of governance and the risk of failure: The case of economic development. International Social Science Journal, 155, 29-45.

Jou, S. C. (1999). Rebuilding the old Taipei: An analysis of urban renewal policy. National Taiwan University Journal of Geographical Science, 25, 15-44.

Jou, S. C., Wu, H. L., \& Chiang, S. S. (2009). Post-industrializing Taipei and neoliberal urban politics. The Journal of Chinese Geography, 43, 15-32.

Kang, Y. (2001). Understanding Shanghai. Shanghai: Shanghai People Publishing House. 
Kazanncigil, A. (1998). Governance and science: Market-like modes of managing society and producing knowledge. International social Science Journal, 155, 67-79.

King, A. D. (1990). Global cities: Post-imperialism and the internationalization of London. London: Routledge.

Kingdom, J. (1995). The European Contest. In M. Mullard (Ed.), Policy-making in Britain: An introduction (pp.50-77). London: Routledgde.

Kooiman, J. (Ed.). (1993). Modern governance: New government-society interactions. London: Sage.

Lake, D. A. (1999). Global governance: A relational contracting approach. In A. Prakash and J. A. Hart (Eds.), Globalization and governance. New York: Routledge.

Lee, C. C. (1997). Gentrification research (1). Report of Executive Yuan National Science Council research project (No. NSC86-2415-H-005A-003) results.

Lee, C. Y. (2012). Regional development and five municipalities governance: Empirical survey analysis. China Local Autonomy, 65(11), 25-46.

Lee, C. Y. (2017). City governance. Baltimore, MD: Angle Publishing.

Lee, Y. J. (2002). Adopting the urban indicators program to measure Taipei's sustainable development. City and Planning, 29(4), 551-574.

Lee, Y. J. (2007). Criteria of a sustainable urban community: New trends in sustainable development of national land. Newsletter for Research of Applied Ethics, 41, 48-57.

Lin, B. C. (2001). Global governance and international safety. International Conference of Global Governance and International Relations, Taipei.

Liu, K. Y. (2001). Changes in governance concepts and states' roles. Conference on States' Roles and Governance Types, Taipei.

Liu, Y. W. (1998). Theories and practice of Taipei city foreign affairs. Master's thesis, Soochow University.

Mingst, K. A. (1999). Global governance: The American perspective. In R. Väyrynen (Ed.), Globalization and global governance (pp. 87-102). New York: Rowman \& Littlefield.

OECD. (1997). Better understanding our cities: The role of urban indicators. Paris: OECD.

Pierre, J., \& Guy Peters, B. (2000). Governance, politics and the state. London: MacMillan.

Rhodes, R. A. W. (1996). The new governance: Governing without government. Political Studies, 44, 652-667.

Rhodes, R. A. W. (2000). Governance and public administration. In Jon Pierre (Ed.), Debating governance: Authority, steering and democracy (pp. 54-90). New York: Oxford.

Rosenau, J. N. (1995). Governance in the twenty-first century. Global Governance, 1, 13-14.

Rosenau, J. N. (2000). Change, complexity, and governance in globalizing space. In Jon Pierre (Ed.), Debating governance: Authority, steering and democracy (pp. 167-200). New York: Oxford.

Rosenau, J. N., \& Czempiel, E. (1992). Governance without government: Order and change in world politics. Cambridge: Cambridge University Press.

Savas, E. (1987). Privatization. In S. P. Seth and C. M. Falbe (Eds.), Business and society: Dimensions of conflict and cooperation. Lexington, KY: D.C. Heath.

Savas, E. (2000). Privatization and public-private partnerships. New Jersey: Chatham, House Publishers.

Short, J. R., \& Kim, Y. (1999). Globalization and the city. New York: Longman.

Smouts, M.-C. (1998). The proper use of governance in international relations. International Social Science Journal, 155, 81-89.

Soong, H. W. (2001). Globalization and global governance, Taiwan's public policy, and implications on Taiwan-China relations. Mainland China Studies, 44(4), 1-31.

Stoker, G. (1998). Governance as theory: Five propositions. International Social Science Journal, 155, 17-28.

The Commission on Global Governance. (1995). Our global neighborhood. Oxford: oxford University Press.

Väyrynen, R. (Ed.). (1999). Globalization and global governance. New York: Rowman \& Littlefield.

Wang, H. P. (2016a). A study on Tokyo metropolitan government's institution: From the perspective of greater area and decentralized governance. Master's thesis, National Taiwan University.

Wang, H. P. (2016b). A study on metropolitan (city) government greater area and decentralized governance: From the perspective of Tokyo metropolitan government's institution. $\mathrm{PhD}$ thesis, National Taiwan University.

Wang, M. D. (2004). Effectiveness evaluation of the public construction civil participation policy and establishment of related operational mechanisms. Project of the Public Construction Commission of Executive Yuan.

Wang, M. D., Chang, C. Y., \& Chou, H. Y. (2008). Integration of the VfM evaluation model into civil participation in public construction in Taiwan. Project of the Public Construction Commission of Executive Yuan. 
Wang, M. D., Huang, M. S., Wang, W. S., Chang, C. Y., \& Chiu, B. C (2004). Analysis of international examples of civil participation in public construction. Project of the Public Construction Commission of Executive Yuan.

Wu, H. C. (2017). A study on decentralized governance in Taiwan's metropolitan cities-A case study of New Taipei City. Master's thesis, National Taiwan University.

Yang, L. X. (1999). Urbanization and city development strategies. Guangdong: Guangdong Higher Education Publishing House. Ye, K. Y. (Ed.). (1995). Spatial political economy. Taipei: Human Publishing. 